\title{
LUT
}

University

Intellectual capital drivers of product and managerial innovation in high-tech and low-tech firms

Buenechea-Elberdin Marta, Kianto Aino, Sáenz Josune

This is a Final draft

version of a publication

published by Wiley

in R\&D Management

DOI: $10.1111 /$ radm. 12271

Copyright of the original publication: ( John Wiley \& Sons

Please cite the publication as follows:

Buenechea-Elberdin, M., Kianto, A., Sáenz, J. (2017). Intellectual capital drivers of product and managerial innovation in high-tech and low-tech firms. R\&D Management, vol. 48, issue 3. pp. 290-307. DOI: $10.1111 / \mathrm{radm} .12271$

This is a parallel published version of an original publication.

This version can differ from the original published article. 


\section{INTELLECTUAL CAPITAL DRIVERS OF PRODUCT AND MANAGERIAL INNOVATION IN HIGH-TECH AND LOW-TECH FIRMS}

\section{ABSTRACT}

There is widespread understanding that intellectual capital (IC), consisting of the valuable knowledge resources of an organization, is a key enabler of innovation activities; however, little is known about the more specific contingencies impacting the relationship between IC and innovation. Thus, this paper examines firm technology level and innovation type as contingency variables. We argue that because high-tech and low-tech firms differ in terms of several knowledge characteristics (complexity, tacitness and pace of renovation), it is likely that their innovation performance is supported by different combinations of IC components. Furthermore, differences between product/service and managerial innovation could also lead to changes in the degree of relevance of various IC components. To test these contingency hypotheses, a survey dataset collected from 180 Spanish companies is analysed using structural equation modelling. The results demonstrate that both firm's technology level and type of innovation affect how IC influences innovation performance. Our findings contribute to a knowledgebased perspective on innovation and pave the way for a more context-sensitive and contingency-mindful approach to understanding innovation and knowledge-based value creation.

\section{KEYWORDS}

Intellectual capital, product and service innovation, managerial innovation, technology level, human capital, structural capital, relational capital, Spain.

\section{INTRODUCTION}

In the current globalized, digitalized and fast-paced economy, the role of knowledge as a valuable organizational resource has gained increasing attention (Drucker, 1993; Nonaka \& Takeuchi, 1995; Grant, 2002). The knowledge-based view of the firm (e.g. Kogut \& Zander, 1992; Grant, 1996; Spender, 1996) argues that sustained company viability and competitiveness are based on the intangible resources and capabilities governed by firms. As knowledge has become a strategic resource, it is increasingly referred to as intellectual capital (Edvinsson \& Malone, 1997; Bontis, 1998; Tseng \& Goo, 2005). From the knowledge-based perspective, innovation management is essentially a question of exploiting the intellectual capital (IC) of a firm (Subramaniam \& Youndt, 2005). Indeed, IC is widely seen to function 
as a crucial enabler of innovation through its main components (human capital, structural capital and relational capital), which represent valuable knowledge embedded in an organization's people, structures and relationships (Cabello-Medina et al., 2011; Delgado-Verde et al., 2014; Aramburu et al., 2015).

Innovations come in many shapes and sizes, from new products and services to novel management and marketing methods, production processes and strategic outlooks (e.g. Oslo Manual, 2005; Bessant \& Tidd, 2007). It is well-known that different innovation types benefit from various antecedents; for example, product innovations can be boosted by a firm's intensity of physical capital and the extent to which the firm develops various innovation projects (Damanpour \& Aravind, 2006), whereas management innovations thrive in organizations where policies and procedures are formalized (Damanpour \& Aravind, 2012). Therefore, it seems likely that the knowledge-based antecedents of innovation would also differ as a function of innovation type. However, while differences between various innovation types have been demonstrated clearly in the more general innovation management literature, there seems to be a lack of understanding concerning what knowledge assets are most important for different types of innovation. Consequently, managers have little guidance regarding which knowledge resources to primarily invest in if they are to support particular types of value-creating novelties in their organizations.

Compared with product and service innovation, innovations in management practices are more internal to individual firms (Damanpour \& Aravind, 2012); hence, they depend more on the idiosyncrasy of each corporation. This suggests that there may also be differences in the degree of relevance of each IC component when it comes to enhancing product/service innovation versus managerial innovation. However, the existing literature analysing the influence of IC on innovation has overlooked comparisons between different innovation types. With the exception of a few studies comparing the influence of various IC components in incremental versus radical innovations (Subramaniam \& Youndt, 2005; Wang \& Chen, 2013), and one study comparing the IC antecedents of product, process and managerial innovation (Elsetouhi et al., 2015), there is little research into how the role of IC differs depending on the type of innovation considered. This paper addresses this gap by analysing the influence of various IC components on both product/service and managerial innovations.

Moreover, just as innovation types vary, the firms producing them differ. Understanding firm characteristics as contingencies in the IC-innovation linkage is important, as various types of firms may 
benefit from different intangibles in their innovation processes. A characteristic likely to be especially influential in determining what intangibles drive innovation is technology level; high- and low-tech companies differ substantially in the type of knowledge they utilise. However, no previous studies have looked at technology level as a contingency variable impacting the role of IC in innovation. In fact, the majority of existing studies on the IC-innovation linkage have examined high-tech firms (e.g. Wu et al., 2007; Martín-de-Castro et al., 2013), while very few have addressed low-tech companies (e.g. Leitner, 2011) and none have compared the two. The lack of understanding about which intangibles matter most for innovation in different types of organizations hinders managers from making informed decisions concerning which IC components they should be investing in and developing to best fit the needs of their firm. Therefore, this study also addresses the question of how the relationships between IC and innovation might vary in different kinds of firms, specifically, by differentiating between high- and low-technology companies.

To empirically examine these issues, we analyse data collected via a structured questionnaire from 180 Spanish firms. The findings demonstrate that product/service and managerial innovations depend on different IC components and that these patterns vary between high- and low-tech firms. Thus, the paper contributes to a knowledge-based perspective on innovation and its management.

\section{THEORETICAL BACKGROUND AND HYPOTHESES}

\subsection{Intellectual capital}

The IC perspective of management evolved in the early 1980s from the needs of business practitioners to better understand the basis of organizational performance and it was consolidated throughout the 1990s as a legitimate and popular academic approach (Bontis, 1998; Petty \& Guthrie, 2000; Dumay, 2014). The IC perspective is ultimately grounded in knowledge-based strategy theory, which traces the sources of competitiveness to intangible resources and capabilities (Kogut \& Zander, 1992; Grant, 1996; Spender, 1996). IC research evolved in three stages: the first stage (from early 1980 to the mid-1990s) focused on "consciousness raising and creating mass awareness of the relevance of intellectual capital" (Petty \& Guthrie, 2000, p. 162); the second stage (from late 1990s to early 2000) aimed to measure and manage IC (Petty \& Guthrie, 2000), as well as analysing the influence of IC on financial outcomes (Dumay \& Garanina, 2013); finally, the third stage focuses on a bottom-up understanding of how IC works in practice (Dumay \& Garanina, 2013). 
Together with the evolution of IC research, its definition and components have also evolved. The countless definitions of IC published in books and journal articles can be classified into two groups: knowledge-based and holistic (Sáenz \& Aramburu, 2011). The knowledge-based perspective conceives IC as the knowledge resources used by the firm to gain competitive advantages, whereas the holistic perspective understands IC as the sum of knowledge resources and other intangible assets the firm manages (Sáenz \& Aramburu, 2011). This research adopts the knowledge capital perspective; thus, IC is defined as all valuable knowledge-related resources that an organisation controls or has access to and manages in order to gain sustainable competitive advantages.

Regardless of perspective, IC is split into different components. The seminal papers published by Bontis (1998) and Subramaniam and Youndt (2005) distinguished between human, structural and customer capital, and human, social and organisational capital, respectively. According to Reed et al. (2006), "while the terms to label the various IC components may differ, conceptually IC consists of three basic components: human, organizational, and social capital, the last containing both external and internal dimensions" (p. 870). These three IC components (i.e. human, organisational/structural and social capital) are widely regarded as the traditional IC framework and is the one preferred by researchers. Consequently, this research applies the traditional IC framework and IC will thus be split into human, structural and relational capital. In the following, each IC component is described in more detail.

Human capital (HC) encompasses organizational members and their attributes, such as knowledge, skills, experience, attitudes and motivation (Edvinsson \& Malone, 1997; Stewart, 1997; Bontis, 1998). HC is considered the cornerstone of IC, although it is not under complete management control: employees are the real owners of HC and companies can only rent employees' HC in exchange for a salary (Roos et al., 1998).

Structural capital (SC) consists of the knowledge accumulated and distributed through firms' structures and processes, such as information systems, cultural traits and management systems (Edvinsson \& Malone, 1997; Stewart, 1997; Bontis, 1998). SC includes both infrastructural assets that form the context for activities and codified knowledge such as documents, databases and intellectual property rights.

Internal relational capital (IRC) is the knowledge embedded in and available for the firm through the webs of relationships among its members (Nahapiet \& Ghoshal, 1998; Kianto \& Waajakoski, 2010). 
External relational capital (ERC) includes knowledge and resources related to the firm's external relationships, such as connections with customers, suppliers, partners and the local community (Edvinsson \& Malone, 1997; Bontis, 1998).

\subsection{Intellectual capital and innovation}

Innovation is substantially related to knowledge. It implies the creation of new knowledge, both as an input (new ideas, concepts, prototypes) as well as an outcome (the produced novelty). Thus, a firm's knowledge resources are key enablers of innovation (e.g. Nonaka \& Takeuchi, 1995; Subramaniam \& Youndt, 2005). Previous studies have examined the role of IC in the production of innovations (e.g. Subramaniam \& Youndt, 2005; Menor et al., 2007; Wu et al., 2007; Wu et al., 2008; Leitner, 2011; Carmona-Lavado et al., 2013; Martín-de-Castro et al., 2013), demonstrating that IC is relevant to innovation.

A detailed examination of the impact of IC on innovation makes obvious that employee-related resources enhance innovation. As Carmona-Lavado et al. (2013, p. 149) put it, "previous research has already suggested that intellect, which clearly resides inside the firm's human brains, is an unquestionable facilitator of innovation". Unique employees who own rare knowledge, which totally differs from the knowledge owned by competitors, play a key role in the development of innovations (Cabello-Medina et al., 2011). Hence, the following hypothesis is suggested:

H1 Human capital positively affects: (a) Product/service innovation in both (i) high-tech and (ii) lowtech firms; and (b) Managerial innovation in both (i) high-tech and (ii) low-tech firms.

In addition, structural capital contributes significantly to innovation by providing knowledge codified and stored in databases, written procedures and information systems, as well as state-of-the-art processes and technology for integrating different work processes (Menor et al., 2007; Wu et al., 2007; Wang \& Chen, 2013). Therefore, the next hypothesis is suggested:

H2 Structural capital positively affects: (a) Product/service innovation in both (i) high-tech and (ii) lowtech firms; and (b) Managerial innovation in both (i) high-tech and (ii) low-tech firms.

Subramaniam and Youndt (2005) emphasized the collaborative nature of the innovation process (p. 459); thus, the internal relationships among managers and employees that facilitate knowledge sharing (i.e. 
internal relational capital) are crucial in the development of innovations (Nonaka \& Takeuchi, 1995; Carmona-Lavado et al., 2010). Consequently:

H3 Internal relational capital positively affects: (a) Product/service innovation in both (i) high-tech and (ii) low-tech firms; and (b) Managerial innovation in both (i) high-tech and (ii) low-tech firms.

Moreover, all knowledge important for innovation cannot possibly reside within a single particular firm. In other words, the creation of new knowledge and the development of new combinations of existing knowledge (i.e. innovation) (Eisenhardt \& Martin, 2000) may require external sources of knowledge that provide indispensable information about customers, suppliers and other strategic partners (Wu et al., 2007; Hsu \& Fang, 2009). Thus, the following hypothesis is posed:

H4 External relational capital positively affects: (a) Product/service innovation in both (i) high-tech and (ii) low-tech firms; and (b) Managerial innovation in both (i) high-tech and (ii) low-tech firms.

\subsection{The role of IC in innovation in high-tech and low-tech firms}

We claim along with Reed et al. (2006) that context matters for how knowledge resources are used in value creation. One important contingency factor in the IC-innovation relationship is the technology level of a given firm. According to De Carolis (2010), high-technology industries are characterised by rapid advances in science and technology, requiring firms to move very quickly to sustain a technological edge and bring new products to the market. Moreover, high-tech usually involves more complex knowledge (i.e. knowledge with many underlying components and/or many interdependencies between those components) and a greater degree of tacitness (Schilling, 2011) than low-tech. Consequently, knowledge residing in firms operating in high- and low-technology industries will differ significantly, which is likely to generate remarkable differences in the IC-innovation linkage.

A deeper analysis of the role of a firm's technology level in the IC-innovation relationship shows that the superior knowledge complexity (Schilling, 2011) and speed of knowledge renewal (De Carolis, 2010) characterising high-tech industries makes necessary employees who are highly knowledgeable and skilful. This is consistent with Delgado-Verde et al. (2015), who demonstrated that employees' education, training, experience and abilities significantly promote innovation in high-tech firms. Conversely, in lowtech companies the competency demands of innovation are likely less sophisticated. Therefore: 
H5 The influence of human capital on (a) product/service and (b) managerial innovation performance is significantly larger in high-tech firms than in low-tech firms.

As high-tech companies deal largely with tacit knowledge (Schilling, 2011), which is difficult to codify and transfer (Nonaka \& Takeuchi, 1995), their innovation efforts will benefit to a lesser extent from knowledge stored in manuals, databases and written procedures. On the contrary, as easy-to-codify knowledge is more frequent in low-tech firms, these companies could benefit to a larger extent from knowledge stored in databases and information systems. Hence, the following hypothesis is formulated:

H6 The influence of structural capital on (a) product/service and (b) managerial innovation performance is significantly lower in high-tech firms than in low-tech firms.

In addition, the greater degree of tacitness of knowledge managed in high-tech companies (Schilling, 2011) makes internal relationships among employees even more relevant. As Nonaka and Takeuchi (1995) point out, tacit knowledge can only be transferred by means of social interaction. Along these lines, Delgado-Verde et al. (2011) demonstrated the positive influence of such interaction among employees on innovation in high-tech firms. In contrast, social interaction in low-tech companies becomes less relevant as explicit knowledge (i.e. knowledge that can be easily codified and transferred) is more present. Thus:

H7 The influence of internal relational capital on (a) product/service and (b) managerial innovation performance is significantly larger in high-tech firms than in low-tech firms.

Relying on relationships with customers, suppliers and key strategic partners is equally necessary for both high- and low-tech companies. Low-tech companies often lack internal innovation capabilities, which makes knowledge from external sources extremely relevant. In high-tech firms, however, although wellestablished internal innovation capabilities may exist, superior knowledge complexity (Schilling, 2011) makes it difficult for one firm to have all the knowledge needed to develop a particular innovation. Hence, external cooperation becomes critical. Moreover, high-tech products are usually 'competence destroying' as they require customers to acquire new knowledge to use them. Consequently, intense relationships with customers are highly beneficial for innovation (Meeus \& Edquist, 2006, p. 29). As a result, the following hypothesis is suggested: 
H8 The influence of external relational capital on (a) product/service and (b) managerial innovation performance is equally relevant in both high- and low-tech firms.

\subsection{IC and product/service vs. managerial innovations}

According to the Oslo Manual (2005), innovation can be divided into novelties introduced in products and services, processes, marketing practices and organizational advancements. Product innovation, which includes services, refers to "the introduction of a good or service that is new or significantly improved with respect to its characteristics or intended uses" (Oslo Manual, 2005, p. 48). Organizational innovation "is the implementation of a new organisational method in the firm's business practices, workplace organisation or external relations" (Oslo Manual, 2005, p. 51). According to Damanpour and Aravind (2012) the terms organizational and administrative innovations have lost relevance in favour of management innovation. Thus, this study uses the term managerial innovation.

The relevance of distinguishing between innovation types was already highlighted in the seminal paper published by Damanpour in 1987 , which argued that the inability to develop a reliable theory on innovation adoption was partly due to the failure to distinguish between various types of innovation when doing research, which provokes finding instability (p. 675).

A thorough analysis into the differences embedded into various innovation types shows that human capital, unlike other IC components, is equally relevant for both product/service and managerial innovation. Because knowledgeable and skilful employees are a firm's most important knowledge asset (Wright et al., 1994) and innovation is intrinsically a human activity, both product/service and managerial innovation will be greatly dependent on workers' capabilities. Thus:

H9 Human capital is equally relevant for both product/service and managerial innovation performance in both (a) high-tech and (b) low-tech firms.

Concerning structural capital, managerial innovations imply changes in the structure of the firm that profoundly alter the inner workings of the company. "Whereas the introduction of a technological innovation does not require reassignments of corporate functions and responsibilities ... the introduction of a major administrative innovation typically requires major reassignments of tasks and responsibilities in a fashion which needs not leave all personnel unambiguously better off' (Teece, 1980, p. 465). Managerial innovations imply new approaches "for performing the work of management and new 
processes that produce changes in the organization's strategy, structure, administrative procedures, and systems" (Damanpour \& Aravind, 2012, p. 429-432). Hence, these changes benefit from knowledge codification. Consequently:

H10 Structural capital is more relevant for managerial innovation performance than for product/service innovation performance in both (a) high-tech and (b) low-tech firms.

In contrast to product/service innovations, which are introduced to satisfy client needs (Damanpour \& Aravind, 2012), managerial innovations are characterised by an internal-to-the-firm approach as they are introduced to enhance "the efficiency and effectiveness of firms' management processes and administrative systems" (Damanpour \& Aravind, 2012, p. 428). Product/service innovations need external verification while managerial innovations should meet firm's internal needs. Thus, the internal exchange of knowledge among employees (i.e. internal relational capital) will greatly enhance managerial innovations, while new knowledge coming from customers, suppliers and strategic partners (i.e. external relational capital) will primarily promote product/service innovations. Consequently, the following hypotheses are proposed:

H11 Internal relational capital is more relevant for managerial innovation performance than for product/service innovation performance in both (a) high-tech and (b) low-tech firms.

H12 External relational capital is more relevant for product/service innovation performance than for managerial innovation performance in both (a) high- tech and (b) low-tech firms.

\subsection{Control variables}

This study also includes size and industry in the model as control variables. Small firms evidence few hierarchical levels, simple procedures and short communication lines, which makes them flexible and agile (Nooteboom, 1994). They have fewer resources than big corporations (Nooteboom, 1994), but the increasing relevance of cooperation among firms helps to overcome this shortfall. Therefore, we suggest that size will exert a negative effect on innovation. Regarding industry, it is widely agreed that innovation propensity could change from one industry to another (Lee, 2005; Jiang et al., 2012). Thus, manufacturing and service firms were distinguished. 
Figure 1 summarises the research model.

\section{INSERT FIGURE 1 HERE}

\section{Figure 1. Research model}

\section{RESEARCH METHODS}

\subsection{Sample and data collection}

The population of this study comprises Spanish companies with 100 employees or more. We used the SABI database (Sistema de Análisis de Balances Ibéricos; System of Iberian Balance Sheet Analysis) to identify firms; this database contains the registered annual accounts of around 2,500,000 Spanish and Portuguese companies. Initially, 1,289 firms met the established criteria and out of these, 700 were contacted by phone during the data collection period, which extended from October 2013 to February 2015 and was executed by the lead author. An attempt was made to balance manufacturing versus service companies and high-tech versus low-tech firms. Confidentiality was guaranteed to all participants in the research.

Firms were classified as high- or low-tech based on the technology-intensity classification of industries suggested by the OECD (Organisation for Economic Co-operation and Development) and EUROSTAT. Industries in higher categories (i.e. high or medium-high technology — in our study, high-tech) have a higher R\&D intensity, whereas industries in lower categories (medium-low or low technology-in our study, low-tech) have a lower R\&D intensity (OECD, 2011).

In total, 180 companies participated in the project (response rate: $25.71 \%$ ) by answering a structured questionnaire. Of these, 86 (47.78\%) were medium-high or high technology firms (i.e. high-techs), and 94 were medium-low or low technology companies (i.e. low-techs). Table 1 provides further details about the sectoral composition of the sample within each technology level.

Regarding profiles of respondents, $89.44 \%$ of participants held a responsible position in their firms, as managing directors $(3.89 \%)$, human resource managers $(67.22 \%)$ or heads of other departments $(18.33 \%)$. The remaining $10.56 \%$ of participants were employees who did not occupy responsible positions.

As data regarding all dependent and independent variables derive from the same self-reported survey, this could lead to the occurrence of what is known as "common method bias" (Podsakoff et al., 2003). To 
determine the extent of method variance in the dataset, a Harman's one-factor test was conducted (Podsakoff \& Organ, 1986). The $35.6 \%$ variance explained by a single factor shows that common method bias is not a major concern in this study.

Table 1. Sample composition

INSERT TABLE 1 HERE

\subsection{Measures}

Measures for IC stocks were developed by Kianto and colleagues based on the sources shown in Table 2 . These scales were tested to ensure their operational validity and psychometric robustness. All measures are based on five-point Likert scales (1: strongly disagree, 5: strongly agree) and all the constructs proposed are reflective in nature. Table 2 shows the specific items used in each latent variable.

Table 2. Constructs and measures

INSERT TABLE 2 HERE

\subsection{Statistical analysis}

Descriptive analyses were performed using SPSS 23 software to show the degree of development of each specific item and of each latent variable within each of the samples under study (high-tech versus lowtech firms). Additional t-tests were then carried out to identify significant variation of values between groups.

The research hypotheses were subsequently tested by means of structural equation modelling based on partial least squares (PLS-Graph software 3.0; Chin \& Frye, 2003), and a multigroup analysis was carried out to determine whether path coefficients differed significantly between high-tech and low-tech firms.

\section{RESULTS}

\subsection{Descriptive analysis}

Table 3 shows the mean and standard deviation of each of the items making up the latent variables, as well as the average value of each of the constructs. Human capital is the only latent variable in which 
significant differences arise between high-tech and low-tech firms. In particular, employees' skills and expertise are significantly higher in high-tech companies compared to low-tech firms.

In addition, the degree of development of each IC component within each sample ("intra-group comparison") is very similar, as is the degree of product/service and managerial innovation performance.

Regarding correlations between latent variables (Table 5), none of them are excessively high. Indeed, the highest correlation found is 0.574 .

Table 3. Descriptive analysis

INSERT TABLE 3 HERE

\subsection{Measurement model evaluation}

Because all constructs were deemed to be reflective, individual item reliability (i.e. indicators' loading above 0.707 ), construct reliability (i.e. composite reliability above 0.8 ), convergent validity (i.e. average variance extracted or AVE over 0.5) and discriminant validity (i.e. constructs sharing more variance with their own indicators than with other constructs) were verified (Tables 4 and 5).

Table 4. Measurement model evaluation Part I

INSERT TABLE 4 HERE

Table 5. Measurement model evaluation Part II (discriminant validity)

INSERT TABLE 5 HERE

As both tables reveal, all parameters show adequate values, excepting the loadings of two indicators: $\mathrm{HC} 2$ in the case of product/service innovation in high-tech and low-tech firms ( 0.653 and 0.648 , respectively) and IRC1 in the case of product/service innovation in low-tech firms (0.691). As they are very close to the established acceptable limit for individual item reliability $(0.707)$, both indicators were retained. 


\subsection{Structural model evaluation}

Table 6 shows the extent to which hypotheses 1 through 4 are satisfied in both high-tech and low-tech firms, as well as the amount of variance explained $\left(\mathrm{R}^{2}\right)$ for each endogenous construct (innovation performance).

Table 6. Structural model evaluation

INSERT TABLE 6 HERE

Table 6 shows that human capital positively and significantly affects both product/service and managerial innovation in high-tech firms, whereas its influence on innovation in low-tech companies is nonsignificant. Thus, hypotheses H1ai and H1bi are satisfied, whereas hypotheses H1aii and H1bii are rejected. The influence of structural capital on innovation is always positive and significant with one exception: product/service innovation in high-tech firms. Hence, hypotheses H2aii, H2bi and H2bii are accepted, whereas hypothesis H2ai is rejected. In contrast, the direct influence of internal relational capital on innovation is never significant. Therefore, hypothesis $\mathrm{H} 3$ is fully rejected. Finally, the direct influence of external relational capital on innovation is only significant for product/service innovation. Consequently, hypothesis H4ai and H4aii are accepted, and hypotheses H4bi and H4bii are rejected.

Table 7 shows the results of the multigroup analysis. The degree of influence of human capital on product/service innovation is significantly larger in high-tech firms than in low-tech companies and it is also very close to being significantly larger in managerial innovation. Thus, hypothesis H5a is satisfied, but hypothesis H5b is not. Conversely, the influence of structural capital on both product/service and managerial innovation is significantly lower in high-tech firms than in low-tech companies. Hence, hypothesis H6 is fully accepted. No significant differences were found for internal relational capital between high-tech and low-tech firms. Therefore, hypothesis $\mathrm{H} 7$ is rejected. The same is true for external relational capital, which was predicted by hypothesis H8. Thus, that hypothesis is accepted.

Table 7. Multigroup analysis

INSERT TABLE 7 HERE

Regarding innovation type, as both product/service and managerial innovation are present in both hightech and low-tech firms, a multigroup test is not needed. Table 6 shows that the influence of human 
capital on product/service and managerial innovation is very similar in high-tech $(0.207$ versus 0.184$)$ and in low-tech firms, although in this case its influence is non-significant. Therefore, hypothesis H9 is satisfied. However, the degree of influence of structural capital on innovation is noticeably larger for managerial innovation than for product/service innovation in both high-tech $(0.270$ versus 0.054$)$ and low-tech firms (0.511 versus 0.358). Hence, hypothesis H10 is accepted. Regarding internal relational capital, its influence on innovation is equally irrelevant in all cases, whereas the influence of external relational capital is larger on product/service innovation than on managerial innovation in both high-tech (0.211 versus 0.082$)$ and low-tech $(0.238$ versus 0.125$)$ firms. Thus, hypothesis H11 is rejected, while hypothesis $\mathrm{H} 12$ is accepted.

Finally, regarding control variables, firm size is the only variable that exerts significant influence on innovation (more specifically, on product/service innovation) in high-tech firms. As can be observed, the smaller the high-tech company, the better the product/service innovation performance.

\subsection{Post hoc analyses}

Several IC components do not exert a significant direct influence on innovation (hypotheses 1 to 4), raising the question about the real meaning of these results: is this because the affected components are truly irrelevant or because their influence may take place through other IC components? To disentangle this, we verified whether each non-significant IC component in the full model exerted a significant influence on innovation when taken in isolation. If such were the case, a mediation effect could be operating, whereas if not, the component under study is definitely irrelevant.

These post hoc analyses reveal that, in the case of product/service innovation, structural capital and internal relational capital are definitely irrelevant in high-tech companies, whereas the same happens with human capital and internal relational capital in low-tech firms.

However, in the case of managerial innovation, internal and external relational capital appear to affect innovation through their influence on human capital and structural capital in high-tech firms (see Figure 2), whereas in low-tech companies, human capital, internal relational capital and external relational capital could be affecting innovation through their influence on structural capital (see Figure 3). 
INSERT FIGURE 2 HERE

Figure 2. Post hoc analyses: Potential indirect effects on MIP in HT firms

INSERT FIGURE 3 HERE

Figure 3. Post hoc analyses: Potential indirect effects on MIP in LT firms

To analyse the degree of significance of these potential indirect effects, bootstrapping techniques were used by means of PLS-Graph software. For high-tech firms (Table 8), the results obtained support the existence of an indirect influence of internal relational capital through human and structural capital on managerial innovation, as well as supporting the existence of such an influence of external relational capital through human capital, but not through structural capital. Finally, for low-tech firms (Table 9), the results obtained support the existence of an indirect influence of human capital and internal relational capital on managerial innovation through structural capital, but not for external relational capital.

Table 8. Post hoc analyses: Exploring potential indirect effects of IRC and ERC through HC and $\mathrm{SC}$ in MIP in HT firms

INSERT TABLE 8 HERE

Table 9. Post hoc analyses: Exploring potential indirect effects of HC, IRC and ERC through SC in MIP in LT firms

INSERT TABLE 9 HERE

\section{DISCUSSION}

This study has analysed how IC components influence product/service and managerial innovation in high and low-tech companies. The extant literature has largely overlooked differences in technology level and innovation type when analysing the IC-innovation relationship. However, this study has demonstrated that such differences must be considered.

In the case of product/service innovation, external relational capital boosts innovation regardless of the technology level of the firm. Both high- and low-tech companies must build solid relationships with customers, suppliers and strategic partners to create successful new products and services. On the contrary, internal relationships seem irrelevant for product/service innovation in both high- and low-tech 
firms. This contrasts with the widely held assumption that internal networks enhance innovation (Carmona-Lavado et al., 2010; Wang \& Chen, 2013); thus, practice does not always carry out the relationship between internal relational capital and innovation.

A key difference between high- and low-tech firms when developing product/service innovation concerns the role of human and structural capital. Human capital has a significant influence on product/service innovation in high-tech companies, whereas structural capital has a larger influence in low-tech firms. Along with Delgado-Verde et al. (2015), highly qualified and skilful employees play a major role in companies managing complex knowledge (Schilling, 2011) that should be frequently renovated (De Carolis, 2010). Moreover, the heavier reliance of low-tech firms on explicit knowledge (which can be easily codified and stored in databases; Nonaka and Takeuchi, 1995) compared to high-tech companies explains the relevance of structural capital in low-tech firms. Additionally, size exerts a negative impact in high-tech companies as large firms are less agile to make decisions and implement innovations (Nooteboom, 1994).

Regarding managerial innovations, structural capital plays a pivotal role in both high- and low-tech firms. The development of new management practices and organizational methods, among others, benefit greatly from knowledge codification. This is especially true in low-tech firms which primarily utilise explicit knowledge (Schilling, 2011), and thus, knowledge that is easy to codify and transfer (Nonaka \& Takeuchi, 1995).

With regard to high-tech firms, human capital, the firm's most relevant knowledge asset (Wright et al., 1994), plays a prominent role in boosting managerial innovations. Additionally, human capital is greatly enhanced by the knowledge generated from the relationships among employees (internal relational capital) and by the relationships of the company with external agents (external relational capital). Moreover, the relationships among employees (internal relational capital) also contribute to strengthening structural capital. Consequently, though managerial innovations have an internal-to-the-firm approach (Damanpour \& Aravind, 2012), the relationships among employees do not per se influence innovation; however, they contribute to enhancing both employees' qualifications and motivation as well as the codified knowledge of the company. Moreover, interactions with external agents increase employees' qualification and motivation; thus, although the internal-to-the-firm approach is characteristic of managerial innovations, employees benefit from knowledge coming from outside the boundaries of the 
company for the development of organizational systems more suitable for managing complex knowledge (Schilling, 2011) that should be frequently renovated (De Carolis, 2010).

Considering low-tech firms, human capital, as well as internal and external relational capital, promote managerial innovation by means of structural capital. Even though human capital is fundamental for enhancing innovation (Carmona-Lavado et al., 2013), the lower complexity of the knowledge managed by low-tech firms (Schilling, 2011) justifies the role of employees' knowledge and motivation as mere promoters of structural capital. As for high-tech companies, the knowledge generated in the relationships among employees has no direct influence on innovation; however, this knowledge should be codified and stored in firm's databases and information systems to enhance innovation. Similarly, external relationships between employees and external agents directly promote structural capital. The influence of both internal and external relational capital when enhancing managerial innovations contrasts with the internal-to-the-firm approach characteristic of these types of innovations. Thus, it may be that either more contingency variables are affecting the IC-innovation relationship or that managerial innovations present more nuanced characteristics that should be deeply explored, or both.

\section{CONCLUSIONS}

This paper focuses on the intellectual capital antecedents of product/service and managerial innovation in high- and low-tech companies. Our findings demonstrate that the IC-innovation linkage differs depending on (a) the type of innovation studied, and (b) the technology level of the innovating organization. Regarding innovation type, the obtained results align with those of Damanpour (1987), showing that different innovation types are not equally related to the same organisational factors. Our findings demonstrate that product/service and managerial innovation need different combinations of IC components. This clearly reinforces the relevance of considering different types of innovation. Regarding technology level, this study confirms the argument of Reed et al. (2006) that context influences how knowledge resources are used in value creation. This study demonstrates that differences set by technology level on such resources influence how IC affects innovation.

Overall, the paper makes two main contributions. First, it points out the knowledge-based differences ingrained in various innovation types. Contrary to other studies addressing the IC-innovation relationship, this paper places the differences between product/service and managerial innovation in a prominent position. Scholars in the field of innovation management may find this paper useful in 
exploring the specific IC antecedents of product/service and managerial innovation on one hand, and based on that learning, in discovering more nuanced differences between product/service and managerial innovation, on the other.

Second, this paper extends the discussion on the contingency perspective of IC initiated by Subramaniam and Youndt (2005) and Reed et al. (2006). This perspective is based on the assumption that the impact of IC on performance varies in differing contexts (Drazin \& Van de Ven, 1985). Our study expands the understanding of the contingency issues that influence how intellectual capital supports innovation by pointing out how the IC-innovation link plays out in the case of product/service versus managerial innovation and high-tech versus low-tech firms.

\subsection{Managerial implications}

Bearing in mind that product/service and managerial innovation in high- and low-tech firms are differently affected by IC, managers should adopt targeted IC management. Managers should be aware that product/service and managerial innovations need different IC antecedents and that innovation is not equally promoted in high- and low-tech companies. In the following, suggestions for enhancing each of the IC components analysed in this paper are proposed.

It is highly recommended that managers continually perform human capital audits in order to discover the real gaps embedded in employees' qualifications, skill base and motivation. Taking into consideration the type of innovation the company wants to develop and the technology level of the firm, managers should first identify what their employees need; thus, the actions they take will be optimally aligned with the existing human capital gap.

Because structural capital is largely enhanced by other IC components, managers should have a clear idea of the type of innovation they want to create and the firm's technology level; this informs which other IC components will boost structural capital. Thus, practitioners will more efficiently use the limited resources they have for promoting innovation. Additionally, because structural capital contains knowledge that will be used by the employees of the company, it is of utmost importance to take into consideration employees' opinion when improving existing databases and information systems.

Regarding internal relational capital, managers should avoid taking for granted that as long as employees have trusting relationships and share useful knowledge, new products and services will be easily 
developed. Instead, managers should understand that internal relationships may not be crucial for developing certain types of innovations and should organise their limited resources accordingly.

Finally, promotion of external relationships is highly dependent on the industry to which the company belongs. Some sectors are very active in organizing workshops and conferences where professional firms gather together and share knowledge. Moreover, maintaining regular interactions with customers through meetings, phone calls, questionnaires and lotteries, among others, could provide relevant knowledge for innovating.

\subsection{Limitations and future research}

The research reported here has some limitations. First, the sample analysed consisted only of Spanish firms. Consequently, some of the findings could be affected by national characteristics. Thus, future research should consider testing this model in other national contexts.

Second, data was provided by only one person in each firm. However, a Harmon one-factor test was conducted (Podsakoff \& Organ, 1986), which revealed that common method effects are not contaminating the results presented here.

Third, this paper focuses on four IC components. Future research could enlarge the models developed here by including other components, such as renewal capital (Kianto et al., 2010) or entrepreneurial capital (Erikson, 2002). Additionally, there are probably other important contingency variables (e.g. manufacturing versus services firms) and other innovation types (e.g. business model innovation and process innovations) that could be analysed.

Lastly, since innovation is intrinsically grounded in knowledge, future research could explore the influence of innovation on strengthening IC. Indeed, Marqués et al. (2006) suggested that it is innovation that actually feeds IC, rather than the other way around. Case study methodology could be applied to examine the causality of the innovation-IC linkage in depth, which might offer valuable insights concerning the ways innovation affects a company's knowledge base.

\section{REFERENCES}

Aramburu, N., Sáenz, J., and Blanco, C. (2015) Structural Capital, Innovation Capability, and Company Performance in Technology-Based Colombian Firms. Cuadernos de Gestión, 15, 1, 39-60.

Bessant, J. and Tidd, J. (2007) Innovation and Entrepreneurship. Chichester, West Sussex, UK: Wiley. 
Bontis, N. (1998) Intellectual capital: An exploratory study that develops measures and models. Management Decision, 36, 2, 63-76.

Cabello-Medina, C., López-Cabrales, Á. and Valle-Cabrera, R. (2011) Leveraging the innovative performance of human capital through HRM and social capital in Spanish firms. The International Journal of Human Resource Management, 22, 4, 807-828.

Carmona-Lavado, A., Cuevas-Rodríguez, G. and Cabello-Medina, C. (2010) Social and organizational capital: Building the context for innovation, Industrial Marketing Management, 39, 681-690.

Carmona-Lavado, A., Cuevas-Rodríguez, G. and Cabello-Medina, C. (2013) Service innovativeness and innovation success in technology-based knowledge-intensive business services: An intellectual capital approach. Industry and Innovation, 20, 2, 133-156.

Chin, W.W. and Frye, T. (2003) PLS-Graph Version 3.00. Build 1017. Texas: University of Houston.

Damanpour, F. (1987) The adoption of technological, administrative, and ancillary innovations: Impact of organizational factors. Journal of management, 13, 4, 675-688.

Damanpour, F. and Aravind, D. (2006) Product and process innovations: A review of organizational and environmental determinants. In: Hage, J., and Meeus, M. (eds), Innovation, Science, and Institutional Change. Oxford: Oxford University Press, pp. 38-66.

Damanpour, F. and Aravind, D. (2012) Managerial innovation: Conceptions, processes, and antecedents. Management and Organization Review, 8, 2, 423-454.

De Carolis, D.M. (2010) Technological Characteristics of Industries. In: Narayanan, V.K. and ColarelliO’Connor, G. (eds.), Encyclopedia of Technology and Innovation Management. Chichester, West Sussex, UK: Wiley. pp. 77-79.

Delgado-Verde, M., Navas-López, J.E., Cruz-González, J. and Amores-Salvado, J. (2011) Radical innovation from relations-based knowledge: empirical evidence in Spanish technology-intensive firms. Journal of Knowledge Management, 15, 5, 722-737.

Delgado-Verde, M., Martín-de-Castro, G., Navas-López, J. E. and Amores-Salvadó, J. (2014) Vertical relationships, complementarity and product innovation: an intellectual capital-based view. Knowledge Management Research \& Practice, 12, 226-235.

Delgado-Verde, M., Cooper, S. and Castro, G.M.D. (2015) The moderating role of social networks within the radical innovation process: a multidimensionality of human capital-based analysis. International Journal of Technology Management, 69, 2, 117-138.

Drazin, R. and Van de Ven, A. (1985) Alternative forms of fit in contingency theory. Administrative Science Quarterly, 30, 514-539.

Drucker, P. F. (1993) The rise of the knowledge society. The Wilson Quarterly, 17, 2, 52-71.

Dumay, J. (2014) 15 years of the journal of intellectual capital and counting: a manifesto for transformational IC research. Journal of Intellectual Capital, 15, 1, 2-37.

Dumay, J. and Garanina, T. (2013) Intellectual capital research: a critical examination of the third stage. Journal of Intellectual Capital, 14, (1), 10-25.

Edvinsson, L. and Malone, M. (1997) Intellectual Capital: Realising your company's true value by finding its hidden brainpower. New York: Harper Collins.

Eisenhardt, K.M. and Martin, J.A. (2000) Dynamic capabilities: What are they? Strategic Management Journal, 21, 1105-1121. 
Elsetouhi, A., Elbeltagi, I. and Haddoud, M.Y. (2015) Intellectual capital and innovations: is organisational capital a missing link in the service sector? International Journal of Innovation Management, 19, 2, 1-29.

Erikson, T. (2002) Entrepreneurial Capital: the Emerging Venture's Most Important Asset and Competitive Advantage. Journal of Business Venturing, 17, 275-290.

Grant, R.M. (1996) Toward a knowledge-based theory of the firm. Strategic Management Journal, 17, S2, 109-122.

Grant, R.M. (2002) Contemporary strategy analysis. (4th Ed.) Massachusetts, USA: Blackwell Publishers Inc.

Hsu, Y.H. and Fang, W. (2009) Intellectual capital and new product development performance: The mediating role of organizational learning capability. Technological Forecasting and Social Change, 76, 5, 664-677.

Jiang, J., Wang, S., and Zhao, S. (2012) Does HRM Facilitate Employee Creativity and Organizational Innovation? A Study of Chinese Firms. International Journal of Human Resource Management, 23, 4025-4047.

Kianto, A. (2008) Development and Validation of a Survey Instrument for Measuring Organizational Renewal Capability. International Journal of Technology Management, 42, 1/2, 69-88.

Kianto, A., Hurmelinna-Laukkanen, P. and Ritala, P. (2010) Intellectual Capital in Service- and ProductOriented Companies. Journal of Intellectual Capital, 11, 3, 305-325.

Kianto, A. and Waajakoski, J. (2010) Linking social capital to organizational growth. Knowledge Management Research \& Practice, 8, 4-14.

Kogut, B. and Zander, U. (1992) Knowledge of the firm, combinative capabilities, and the replication of technology. Organization science, 3, 3, 383-397.

Lee, P.M. (2005). A Comparison of Ownership Structures and Innovations of US and Japanese Firms. Managerial and Decision Economics, 26, 39-50.

Leitner, K.H. (2011) The Effect of Intellectual Capital on Product Innovativeness in SMEs. International Journal of Technology Management, 53, 1, 1-18.

Marqués, D.P., Simón, F.J.G. and Carañana, C.D. (2006) The effect of innovation on intellectual capital: an empirical evaluation in the biotechnology and telecommunications industries. International Journal of Innovation Management, 10, 1, 89-112.

Martín-de-Castro, G., Delgado-Verde, M., Amores-Salvadó, J. and Navas-López, J.E. (2013) Linking human, technological, and relational assets to technological innovation: exploring a new approach. Knowledge Management Research \& Practice, 11, 123-132.

Meeus, M. and Edquist, C. (2006) Introduction to Part I: Product and process innovation. In: Hage, J., and Meeus, M. (eds), Innovation, Science, and Institutional Change. Oxford: Oxford University Press, pp. 2337.

Menor, L.J., Kristal, M.M., and Rosenzweig, E.D. (2007) Examining the Influence of Operational Intellectual Capital on Capabilities and Performance. Manufacturing \& Service Operations Management, 9, 559-578.

Nahapiet, J. and Ghoshal, S. (1998) Social Capital, Intellectual Capital, and the Organizational Advantage. Academy of Management Review, 23, 2, 242-266. 
Nonaka, I., and Takeuchi, H. (1995) The knowledge-creating company: How Japanese companies create the dynamics of innovation, Oxford: Oxford university press.

Nooteboom, B. (1994) Innovation and diffusion in small firms: Theory and evidence. Small Business Economics, 6, 327-347.

OECD (2005) Oslo manual: Guidelines for collecting and interpreting innovation data, Paris: OECD Publishing.

OECD (2011) ISIC Rev.3 Technology Intensity Definition - Classification of Manufacturing Industries into Categories based on R\&D Intensities.

Petty, R., and Guthrie, J. (2000) Intellectual capital literature review: measurement, reporting and management. Journal of Intellectual Capital, 1, 2, 155-176.

Podsakoff, P.M., MacKenzie, S.B., Lee, J.Y. and Podsakoff, N.P. (2003) Common method biases in behavioral research: A critical review of the literature and recommended remedies. Journal of Applied Psychology, 88, 5, 879-903.

Podsakoff, P.M., and Organ, D.W. (1986) Self-Reports in Organizational Research: Problems and Prospects. Journal of Management, 12, 69-82.

Reed, K., Lubatkin, M. and Srinivasan, N. (2006) Proposing and testing an intellectual capital-based view of the firm. Journal of Management Studies, 43, 4, 867-893.

Roos, J., Roos, G., Dragonetti, N.C. and Edvinsson, L. (1998) Intellectual Capital: Navigating in the New Business Landscape. New York: New York University Press.

Sáenz, J. and Aramburu, N. (2011) Towards a new approach for measuring innovation: The innovationvalue path. In: Vallejo, B., Rodriguez, A., and Arregui, G. (eds), Identifying, measuring, and valuing knowledge-based intangible assets: New perspectives. Hershey, PA: IGI Global, pp. 87-111.

Schilling, M. (2011) Strategic Management of Technological Innovation $-3^{\text {rd }}$ edition, New York, NY: McGraw Hill.

Spender, J.C. (1996) Making knowledge the basis of a dynamic theory of the firm. Strategic Management Journal, 17, Winter Special Issue, 45-62.

Stewart, T. (1997) Intellectual Capital: The New Wealth of Organizations. New York: Doubleday/Currency.

Subramaniam, M. and Youndt, M.A. (2005) The influence of intellectual capital on the types of innovative capabilities. Academy of Management Journal, 48, 3, 450-463.

Teece, D.J. (1980) The diffusion of an administrative innovation. Management Science, 26, 5, 464-470.

Tseng, C.Y. and James Goo, Y.J. (2005) Intellectual capital and corporate value in an emerging economy: empirical study of Taiwanese manufacturers. $R \& D$ Management, 35, 2, 187-201.

Wang D. and Chen, S. (2013) Does intellectual capital matter? High-performance work systems and bilateral innovative capabilities. International Journal of Manpower, 34, 8, 861-879.

Weerawardena, J. (2003) Exploring the role of market learning capability in competitive strategy. European Journal of Marketing, 37, 3/4, 407-429.

Wright, P., McMahon, G. and McWilliams, A. (1994) Human Resources and Sustained Competitive Advantage: A Resource-based Perspective. International Journal of Human Resource Management, 3, 301-326. 
Wu, S.H., Lin, L.Y. and Hsu, M.Y. (2007) Intellectual Capital, Dynamic Capabilities and Innovative Performance of Organizations. International Journal of Technology Management, 39, 3-4, 279-296.

Wu, W.-Y., Chang, M.-L. and Chen, C.-W. (2008) Promoting innovation through the accumulation of intellectual capital, social capital, and entrepreneurial orientation. $R \& D$ Management, 38, 3, 265-277.

Yang, C. and Lin, C. (2009) Does Intellectual Capital Mediate the Relationship between HRM and Organizational Performance? Perspective of a Healthcare Industry in Taiwan. International Journal of Human Resource Management, 20, 9, 1965-1984. 
Table 1. Sample composition (1 of 2)

\begin{tabular}{|c|c|c|}
\hline Industry & Frequency & Percentage \\
\hline 20 Manufacture of chemicals and chemical products & 5 & $2.78 \%$ \\
\hline $\begin{array}{l}21 \text { Manufacture of basic pharmaceutical products and pharmaceutical } \\
\text { preparations }\end{array}$ & 3 & $1.67 \%$ \\
\hline 27 Manufacture of electrical equipment & 3 & $1.67 \%$ \\
\hline 28 Manufacture of machinery and equipment n.e.c. & 4 & $2.22 \%$ \\
\hline 29 Manufacture of motor vehicles, trailers and semi-trailers & 14 & $7.78 \%$ \\
\hline 30 Manufacture of other transport equipment & 2 & $1.11 \%$ \\
\hline $\begin{array}{l}50 \text { Motion picture, video and television programme production, sound } \\
\text { recording and music publishing activities }\end{array}$ & 3 & $1.67 \%$ \\
\hline 60 Programming and broadcasting activities & 3 & $1.67 \%$ \\
\hline 61 Telecommunications & 4 & $2.22 \%$ \\
\hline 62 Computer programming, consulting and related activities & 35 & $19.44 \%$ \\
\hline 63 Information service activities & 3 & $1.67 \%$ \\
\hline 72 Scientific research and development & 7 & $3.89 \%$ \\
\hline Medium-high and high technology subtotal & 86 & $47.78 \%$ \\
\hline 10 Manufacture of food products & 15 & $8.33 \%$ \\
\hline 11 Manufacture of beverages & 5 & $2.78 \%$ \\
\hline 12 Manufacture of tobacco products & 1 & $0.56 \%$ \\
\hline 13 Manufacture of textiles & 1 & $0.56 \%$ \\
\hline 14 Manufacturing of wearing apparel & 1 & $0.56 \%$ \\
\hline 15 Manufacture of leather and related products & 2 & $1.11 \%$ \\
\hline 17 Manufacture of paper and paper products & 1 & $0.56 \%$ \\
\hline 18 Printing and reproduction of recorded media & 1 & $0.56 \%$ \\
\hline 22 Manufacture of rubber and plastic products & 4 & $2.22 \%$ \\
\hline 23 Manufacture of other non-metallic mineral products & 2 & $1.11 \%$ \\
\hline 24 Manufacture of basic metals & 6 & $3.33 \%$ \\
\hline $\begin{array}{l}25 \text { Manufacture of fabricated metal products, except machinery and } \\
\text { equipment }\end{array}$ & 7 & $3.89 \%$ \\
\hline 31 Manufacture of furniture & 1 & $0.56 \%$ \\
\hline 32 Other manufacturing & 1 & $0.56 \%$ \\
\hline 33 Repair and installation of machinery and equipment & 1 & $0.56 \%$ \\
\hline 35 Electricity, gas, steam and air conditioning supply & 1 & $0.56 \%$ \\
\hline 36 Water collection, treatment and supply & 1 & $0.56 \%$ \\
\hline 41 Construction of buildings & 1 & $0.56 \%$ \\
\hline 42 Civil engineering & 2 & $1.11 \%$ \\
\hline 43 Specialised construction activities & 1 & $0.56 \%$ \\
\hline 46 Wholesale trade, except of motor vehicles and motorcycles & 3 & $1.67 \%$ \\
\hline 47 Retail trade, except of motor vehicles and motorcycles & 1 & $0.56 \%$ \\
\hline 49 Land transport and transport via pipelines & 8 & $4.44 \%$ \\
\hline 52 Warehousing and support activities for transportation & 1 & $0.56 \%$ \\
\hline 55 Accommodation & 3 & $1.67 \%$ \\
\hline 56 Food and beverage service activities & 2 & $1.11 \%$ \\
\hline
\end{tabular}


Table 1. Sample composition (2 of 2)

\begin{tabular}{lrr}
\hline Industry & Frequency & Percentage \\
\hline 58 Publishing activities & 3 & $1.67 \%$ \\
70 Activities of head offices; management consultancy activities & 2 & $1.11 \%$ \\
71 Architectural and engineering activities; technical testing and analysis & 2 & $1.11 \%$ \\
74 Other professional, scientific and technical activities & 3 & $1.67 \%$ \\
79 Travel agency, tour operator and other reservation service and related & 1 & $0.56 \%$ \\
activities & 2 & $1.11 \%$ \\
81 Services to buildings and landscape activities & 1 & $0.56 \%$ \\
84 Public administration and defence; compulsory social security & 1 & $0.56 \%$ \\
85 Education & 1 & $0.56 \%$ \\
86 Human health activities & 3 & $1.67 \%$ \\
87 Residential care activities & 2 & $1.11 \%$ \\
88 Social work activities without accommodation & $\mathbf{9 4}$ & $\mathbf{5 2 . 2 2 \%}$ \\
\hline Medium-low and low technology subtotal & $\mathbf{1 8 0}$ & $\mathbf{1 0 0 . 0 0 \%}$ \\
\hline Total &
\end{tabular}


Table 2. Constructs and measures

\begin{tabular}{l}
$\begin{array}{l}\text { Constructs and } \\
\text { measures }\end{array}$ \\
\hline
\end{tabular}

\begin{tabular}{|c|c|c|}
\hline $\begin{array}{l}\text { Size } \\
\text { (control variable) }\end{array}$ & --- & Natural logarithm of the number of employees. \\
\hline $\begin{array}{l}\text { Industry } \\
\text { (control variable) }\end{array}$ & --- & Manufacturing firm $=1$; Service firm $=0$ \\
\hline $\begin{array}{l}\text { Human capital } \\
\text { (reflective) } \\
\mathrm{HC} 1 \\
\mathrm{HC} 2 \\
\mathrm{HC} 3\end{array}$ & $\begin{array}{l}\text { Bontis, 1998; } \\
\text { Yang \& Lin, } 2009 .\end{array}$ & $\begin{array}{l}\text { Our employees are highly skilled at their jobs. } \\
\text { Our employees are highly motivated in their work. } \\
\text { Our employees have a high level of expertise. }\end{array}$ \\
\hline $\begin{array}{l}\text { Structural capital } \\
\text { (reflective) }\end{array}$ & $\begin{array}{l}\text { Kianto, 2008; } \\
\text { Kianto et al., }\end{array}$ & \\
\hline $\mathrm{SC} 1$ & 2010. & $\begin{array}{l}\text { Our company has efficient and relevant information systems } \\
\text { to support business operations. }\end{array}$ \\
\hline $\mathrm{SC} 2$ & & $\begin{array}{l}\text { Our company has tools and facilities to support cooperation } \\
\text { between employees. }\end{array}$ \\
\hline $\mathrm{SC} 3$ & & $\begin{array}{l}\text { Our company has a great deal of useful knowledge in } \\
\text { documents and databases. }\end{array}$ \\
\hline SC4 & & Existing documents and solutions are easily accessible. \\
\hline
\end{tabular}

Internal relational Kianto, 2008; capital (reflective) Yang \& Lin, 2009. IRC1

IRC2

IRC3

\section{External relational capital (reflective)}

\section{ERC2}

ERC3

Prod./Serv. innovation perf (reflective) PIP

$\begin{array}{ll}\begin{array}{l}\text { Managerial } \\ \text { innovation perf. }\end{array} & \text { Weerawardena, } \\ \text { (reflective) } & \\ \text { MIP } & \end{array}$

Different units and functions within our company - such as $\mathrm{R} \& \mathrm{D}$, marketing and production - understand each other well.

Our employees frequently collaborate to solve problems. Internal cooperation in our company runs smoothly.

Kianto, 2008

Weerawardena, 2003

Compared to its competitors, how successfully has your company managed to create products and services for customers over the past year?

Compared to its competitors, how successfully has your company managed to create new management practices over the past year? 
Table 3. Descriptive analysis

\begin{tabular}{lrrrrrrr}
\hline \multicolumn{1}{c}{ Items } & Mean HT & \multicolumn{1}{c}{ SD HT } & Mean LT & \multicolumn{1}{c}{ SD LT } & Mean dif. & t-value & p-value \\
\hline HC1 & 4.209 & 0.5763 & 3.745 & 0.6868 & $\mathbf{0 . 4 6 4 6}$ & $\mathbf{4 . 8 9 2}$ & $\mathbf{0 . 0 0 0}$ \\
HC2 & 3.453 & 0.7920 & 3.309 & 0.6883 & 0.1450 & 1.314 & 0.191 \\
HC3 & 4.012 & 0.6416 & 3.809 & 0.5541 & $\mathbf{0 . 2 0 3 1}$ & $\mathbf{2 . 2 6 3}$ & $\mathbf{0 . 0 2 5}$ \\
HC & 3.891 & 0.5150 & 3.621 & 0.5233 & $\mathbf{0 . 2 7 0 9}$ & $\mathbf{3 . 4 9 8}$ & $\mathbf{0 . 0 0 1}$ \\
\hline SC1 & 3.698 & 0.9588 & 3.681 & 0.8061 & 0.1680 & 0.127 & 0.899 \\
SC2 & 3.709 & 0.8794 & 3.553 & 0.8503 & 0.1561 & 1.209 & 0.228 \\
SC3 & 3.884 & 1.0107 & 3.691 & 0.9507 & 0.1922 & 1.311 & 0.192 \\
SC4 & 3.628 & 0.9336 & 3.574 & 0.9559 & 0.0534 & 0.379 & 0.705 \\
SC & 3.730 & 0.7842 & 3.625 & 0.7412 & 0.1046 & 0.918 & 0.360 \\
\hline IR1 & 3.605 & 0.9490 & 3.596 & 0.7804 & 0.0089 & 0.068 & 0.946 \\
IR2 & 3.918 & 0.8621 & 3.819 & 0.7327 & 0.0985 & 0.819 & 0.414 \\
IR3 & 3.512 & 0.9670 & 3.649 & 0.8514 & -0.1373 & -1.013 & 0.312 \\
IR & 3.682 & 0.8324 & 3.689 & 0.6823 & -0.0056 & -0.049 & 0.961 \\
\hline ER1 & 3.905 & 0.6516 & 3.851 & 0.7178 & 0.0537 & 0.523 & 0.602 \\
ER2 & 3.894 & 0.7241 & 3.766 & 0.7248 & 0.1282 & 1.182 & 0.239 \\
ER3 & 3.659 & 0.7489 & 3.713 & 0.7567 & -0.0539 & -0.479 & 0.633 \\
ER & 3.817 & 0.6043 & 3.777 & 0.6286 & 0.0409 & 0.442 & 0.659 \\
\hline PIP & 3.553 & 0.7793 & 3.391 & 0.9716 & 0.1616 & 1.215 & 0.226 \\
\hline MIP & 3.388 & 0.6564 & 3.409 & 0.8876 & -0.0204 & -0.173 & 0.863 \\
\hline
\end{tabular}

Table 4. Measurement model evaluation Part I

\begin{tabular}{|c|c|c|c|c|c|}
\hline \multicolumn{2}{|l|}{ Constructs and measures } & \multirow{2}{*}{$\begin{array}{r}\text { PIP in HT } \\
1.000\end{array}$} & \multirow{2}{*}{$\begin{array}{r}\text { PIP in LT } \\
1.000\end{array}$} & \multirow{2}{*}{$\begin{array}{r}\text { MIP in HT } \\
1.000\end{array}$} & \multirow{2}{*}{$\begin{array}{r}\text { MIP in LT } \\
1.000\end{array}$} \\
\hline Size & $\rho_{\mathrm{c}}$ & & & & \\
\hline & AVE & 1.000 & 1.000 & 1.000 & 1.000 \\
\hline Size & Loadings & 1.000 & 1.000 & 1.000 & 1.000 \\
\hline \multirow[t]{2}{*}{ Industry } & $\rho_{c}$ & 1.000 & 1.000 & 1.000 & 1.000 \\
\hline & AVE & 1.000 & 1.000 & 1.000 & 1.000 \\
\hline Industry & Loadings & 1.000 & 1.000 & 1.000 & 1.000 \\
\hline \multirow{2}{*}{ Human capital } & $\rho_{\mathrm{c}}$ & 0.815 & 0.847 & 0.793 & 0.833 \\
\hline & AVE & 0.598 & 0.653 & 0.565 & 0.627 \\
\hline $\mathrm{HC} 1$ & Loadings & 0.821 & 0.931 & 0.601 & 0.720 \\
\hline $\mathrm{HC} 2$ & & 0.653 & 0.648 & 0.849 & 0.896 \\
\hline $\mathrm{HC} 3$ & & 0.833 & 0.820 & 0.782 & 0.748 \\
\hline \multirow[t]{2}{*}{ Structural capital } & $\rho_{\mathrm{c}}$ & 0.886 & 0.899 & 0.899 & 0.897 \\
\hline & AVE & 0.664 & 0.690 & 0.691 & 0.686 \\
\hline $\mathrm{SC} 1$ & Loadings & 0.870 & 0.754 & 0.823 & 0.821 \\
\hline $\mathrm{SC} 2$ & & 0.710 & 0.849 & 0.813 & 0.866 \\
\hline SC3 & & 0.719 & 0.882 & 0.775 & 0.846 \\
\hline $\mathrm{SC} 4$ & & 0.936 & 0.832 & 0.907 & 0.778 \\
\hline \multirow[t]{2}{*}{ Internal relational capital } & $\rho_{\mathrm{c}}$ & 0.904 & 0.886 & 0.922 & 0.893 \\
\hline & AVE & 0.760 & 0.725 & 0.798 & 0.738 \\
\hline IRC1 & Loadings & 0.771 & 0.692 & 0.880 & 0.727 \\
\hline IRC2 & & 0.909 & 0.951 & 0.866 & 0.918 \\
\hline IRC3 & & 0.926 & 0.890 & 0.932 & 0.918 \\
\hline \multirow[t]{2}{*}{ External relational capital } & $\rho_{\mathrm{c}}$ & 0.884 & 0.882 & 0.882 & 0.890 \\
\hline & AVE & 0.718 & 0.714 & 0.715 & 0.731 \\
\hline ERC1 & Loadings & 0.814 & 0.797 & 0.766 & 0.903 \\
\hline ERC2 & & 0.840 & 0.896 & 0.883 & 0.782 \\
\hline ERC3 & & 0.886 & 0.816 & 0.882 & 0.875 \\
\hline \multirow[t]{2}{*}{ Prod./Serv. innovation perf. } & $\rho_{\mathrm{c}}$ & 1.000 & 1.000 & & \\
\hline & AVE & 1.000 & 1.000 & & \\
\hline PIP & Loadings & 1.000 & 1.000 & & \\
\hline \multirow[t]{2}{*}{ Managerial innovation perf. } & $\rho_{\mathrm{c}}$ & & & 1.000 & 1.000 \\
\hline & AVE & & & 1.000 & 1.000 \\
\hline MIP & Loadings & & & 1.000 & 1.000 \\
\hline
\end{tabular}

Notes: $\rho$ : composite reliability; AVE: average variance extracted; PIP: Product/Service innovation performance; MIP: Managerial innovation performance; HT: High-tech; LT: Low-tech. 
Table 5. Measurement model evaluation Part II (discriminant validity)

\begin{tabular}{|c|c|c|c|c|c|c|c|c|}
\hline \multicolumn{9}{|c|}{ Product/service innovation in high-tech firms } \\
\hline & & 1 & 2 & 3 & 4 & 5 & 6 & 7 \\
\hline 1. & Size & $(1.000)$ & & & & & & \\
\hline 2. & Industry & 0.323 & $(1.000)$ & & & & & \\
\hline 3 . & Human capital & -0.060 & -0.269 & $(0.773)$ & & & & \\
\hline 4. & Structural capital & -0.193 & -0.172 & 0.336 & $(0.815)$ & & & \\
\hline 5. & Internal relational capital & 0.030 & -0.122 & 0.456 & 0.502 & $(0.818)$ & & \\
\hline 6. & External relational capital & -0.064 & -0.237 & 0.441 & 0.296 & 0.405 & $(0.847)$ & \\
\hline 7. & Prod./Serv. innovation perf. & -0.370 & -0.162 & 0.267 & 0.179 & 0.061 & 0.276 & $(1.000)$ \\
\hline \multicolumn{9}{|c|}{ Product/service innovation in low-tech firms } \\
\hline & & 1 & 2 & 3 & 4 & 5 & 6 & 7 \\
\hline & Size & $(1.000)$ & & & & & & \\
\hline 2. & Industry & -0.015 & $(1.000)$ & & & & & \\
\hline 3. & Human capital & -0.002 & -0.007 & $(0.808)$ & & & & \\
\hline 4. & Structural capital & 0.047 & 0.134 & 0.479 & $(0.831)$ & & & \\
\hline 5. & Internal relational capital & -0.065 & 0.058 & 0.558 & 0.517 & $(0.851)$ & & \\
\hline 6. & External relational capital & 0.043 & 0.048 & 0.328 & 0.350 & 0.321 & $(0.845)$ & \\
\hline 7. & Prod./Serv. innovation perf. & 0.003 & 0.080 & 0.111 & 0.367 & 0.162 & 0.312 & $(1.000)$ \\
\hline \multicolumn{9}{|c|}{ Managerial innovation in high-tech firms } \\
\hline & & 1 & 2 & 3 & 4 & 5 & 6 & 7 \\
\hline & Size & $(1.000)$ & & & & & & \\
\hline 2. & Industry & 0.323 & $(1.000)$ & & & & & \\
\hline 3. & Human capital & -0.056 & -0.191 & $(0.752)$ & & & & \\
\hline 4. & Structural capital & -0.193 & -0.186 & 0.438 & $(0.831)$ & & & \\
\hline 5. & Internal relational capital & 0.028 & -0.112 & 0.488 & 0.494 & $(0.893)$ & & \\
\hline 6. & External relational capital & -0.065 & -0.232 & 0.433 & 0.250 & 0.400 & $(0.846)$ & \\
\hline 7. & Managerial innovation perf. & 0.030 & -0.114 & 0.357 & 0.375 & 0.300 & 0.246 & $(1.000)$ \\
\hline \multicolumn{9}{|c|}{ Managerial innovation in low-tech firms } \\
\hline & & 1 & 2 & 3 & 4 & 5 & 6 & 7 \\
\hline & Size & $(1.000)$ & & & & & & \\
\hline & Industry & -0.015 & $(1.000)$ & & & & & \\
\hline 3. & Human capital & 0.049 & -0.069 & $(0.792)$ & & & & \\
\hline 4. & Structural capital & 0.045 & 0.140 & 0.466 & $(0.828)$ & & & \\
\hline 5. & Internal relational capital & -0.068 & 0.050 & 0.574 & 0.517 & $(0.859)$ & & \\
\hline & External relational capital & 0.018 & 0.051 & 0.407 & 0.345 & 0.303 & $(0.855)$ & \\
\hline 7. & Managerial innovation perf. & 0.065 & 0.063 & 0.208 & 0.488 & 0.177 & 0.260 & $(1.000)$ \\
\hline
\end{tabular}

Notes: Diagonal elements are the square root of the variance shared between the constructs and their measures, relative to the amount due to measurement error (AVE). Off-diagonal elements are the correlations among constructs. For discriminant validity, diagonal elements should be larger than off-diagonal elements.

Table 6. Structural model evaluation

\begin{tabular}{llrrrrrrr}
\hline & & \multicolumn{7}{c}{ Exogenous constructs } \\
\hline \multirow{3}{*}{ PIP in HT } & Size & Industry & HC & SC & IRC & \multicolumn{1}{c}{ ERC } & $\mathbf{R}^{\mathbf{2}}$ \\
& Beta & $\mathbf{- 0 . 3 4 5}$ & 0.049 & $\mathbf{0 . 2 0 7}$ & 0.054 & -0.130 & $\mathbf{0 . 2 1 1}$ & $23.52 \%$ \\
& t-value & $\mathbf{3 . 0 6 4 7}$ & 0,4215 & $\mathbf{1 . 6 4 7 7}$ & 0.2907 & 0.8950 & $\mathbf{1 . 6 1 9 4}$ & \\
& p-value & $\mathbf{0 . 0 0 1 1}$ & 0.3368 & $\mathbf{0 . 0 5 0 0}$ & 0.3857 & 0.1856 & $\mathbf{0 . 0 5 3 0}$ & \\
\hline \multirow{3}{*}{ PIP in LT } & Beta & -0.026 & 0.021 & -0.118 & $\mathbf{0 . 3 5 8}$ & -0.037 & $\mathbf{0 . 2 3 8}$ & $18.84 \%$ \\
& t-value & 0.3141 & 0.2069 & 0.9082 & $\mathbf{2 . 8 8 7 7}$ & 0.2212 & $\mathbf{2 . 3 2 4 1}$ & \\
& p-value & 0.3768 & 0.4181 & 0.1821 & $\mathbf{0 . 0 0 2 0}$ & 0.4125 & $\mathbf{0 . 0 1 0 3}$ & \\
\hline \multirow{3}{*}{ MIP in HT } & Beta & 0.110 & -0.041 & $\mathbf{0 . 1 8 4}$ & $\mathbf{0 . 2 7 0}$ & 0.036 & 0.082 & $20.58 \%$ \\
& t-value & 1.1989 & 0.4157 & $\mathbf{1 . 5 8 5 1}$ & $\mathbf{2 . 0 1 7 3}$ & 0.2846 & 0.6034 & \\
& p-value & 0.1156 & 0.3389 & $\mathbf{0 . 0 5 6 8}$ & $\mathbf{0 . 0 2 2 1}$ & 0.3880 & 0,2733 & \\
\hline \multirow{3}{*}{ MIP in LT } & Beta & 0.033 & -0.011 & -0.020 & $\mathbf{0 . 5 1 1}$ & -0.111 & 0.125 & $25.95 \%$ \\
& t-value & 0.3797 & 0.1117 & 0.1582 & $\mathbf{5 . 0 7 4 5}$ & 0.8486 & 1.0063 & \\
& p-value & 0.3522 & 0.4556 & 0.4372 & $\mathbf{0 . 0 0 0 0}$ & 0.1983 & 0.1574 & \\
\hline
\end{tabular}

Notes: p-values based on $\mathrm{t}_{499}$, one-tailed test. 
Table 7. Multigroup analysis

\begin{tabular}{llrrrr}
\hline & Exogenous constructs & Beta (HT) & Beta (LT) & t-value & p-value \\
\hline \multirow{3}{*}{ Product/ } & Size & $\mathbf{- 0 . 3 4 5}$ & $\mathbf{- 0 . 0 2 6}$ & $\mathbf{2 . 3 2 1 8}$ & $\mathbf{0 . 0 1 0 3}$ \\
Service & Industry & 0.049 & 0.021 & 0.1832 & 0.4274 \\
innovation & Human capital & $\mathbf{0 . 2 0 7}$ & $\mathbf{- 0 . 1 1 8}$ & $\mathbf{1 . 8 0 2 4}$ & $\mathbf{0 . 0 3 6 0}$ \\
performance & Structural capital & $\mathbf{0 . 0 5 4}$ & $\mathbf{0 . 3 5 8}$ & $\mathbf{1 . 3 9 0 4}$ & $\mathbf{0 . 0 8 2 5}$ \\
& Internal relational capital & -0.130 & -0.037 & 0.4187 & 0.3378 \\
& External relational capital & 0.211 & 0.238 & 0.1653 & 0.4344 \\
\hline & Size & 0.110 & 0.033 & 0.6132 & 0.2700 \\
Managerial & Industry & -0.041 & -0.011 & 0.2160 & 0.4145 \\
innovation & Human capital & 0.184 & -0.020 & 1.1884 & 0.1176 \\
performance & Structural capital & $\mathbf{0 . 2 7 0}$ & $\mathbf{0 . 5 1 1}$ & $\mathbf{1 . 4 6 2 6}$ & $\mathbf{0 . 0 7 2 1}$ \\
& Internal relational capital & 0.036 & -0.111 & 0.8095 & 0.2093 \\
& External relational capital & 0.082 & 0.125 & 0.2354 & 0.4070 \\
\hline
\end{tabular}

Notes: p-values based on $\mathrm{t}_{499}$, one-tailed test.

Table 8. Post hoc analyses: Exploring potential indirect effects of IRC and ERC through HC and SC in MIP in HT firms

\begin{tabular}{lcccc}
\hline & $\begin{array}{c}\text { Indirect effect of } \\
\text { IRC on MIP } \\
\text { through HC }\end{array}$ & $\begin{array}{c}\text { Indirect effect of } \\
\text { ERC on MIP } \\
\text { through HC }\end{array}$ & $\begin{array}{c}\text { Indirect effect of } \\
\text { IRC on MIP } \\
\text { through SC }\end{array}$ & $\begin{array}{c}\text { Indirect effect of } \\
\text { ERC on MIP } \\
\text { through SC }\end{array}$ \\
\hline Indirect effect & 0.059 & 0.051 & 0.131 & 0.019 \\
t-value & 2.3671 & 1.6679 & 1.9444 & 0.3523 \\
p-value & 0.0183 & 0.0960 & 0.0524 & 0.7247 \\
Mediation & Yes & Yes & Yes & No \\
Direct effect sign. & Non-significant & Non-significant & Non-significant & NA \\
Type of mediation & Full & Full & Full & NA \\
\hline
\end{tabular}

Notes: p-values based on $\mathrm{t}_{499}$, two-tailed test.

Table 9. Post hoc analyses: Exploring potential indirect effects of HC, IRC and ERC through SC in MIP in LT firms

\begin{tabular}{lccc}
\hline & $\begin{array}{c}\text { Indirect effect of } \\
\text { HC on MIP } \\
\text { through SC }\end{array}$ & $\begin{array}{c}\text { Indirect effect of } \\
\text { IRC on MIP } \\
\text { through SC }\end{array}$ & $\begin{array}{c}\text { Indirect effect of } \\
\text { ERC on MIP } \\
\text { through SC }\end{array}$ \\
\hline Indirect effect & 0.120 & 0.188 & 0.085 \\
t-value & 1.7781 & 2.4067 & 1.3014 \\
p-value & 0.0760 & 0.0165 & 0.1937 \\
Mediation & Yes & Yes & No \\
Direct effect sign. & Non-significant & Non-significant & NA \\
Type of mediation & Full & Full & NA \\
\hline
\end{tabular}

Notes: p-values based on $\mathrm{t}_{499}$, two-tailed test. 
Figure 1. Research model

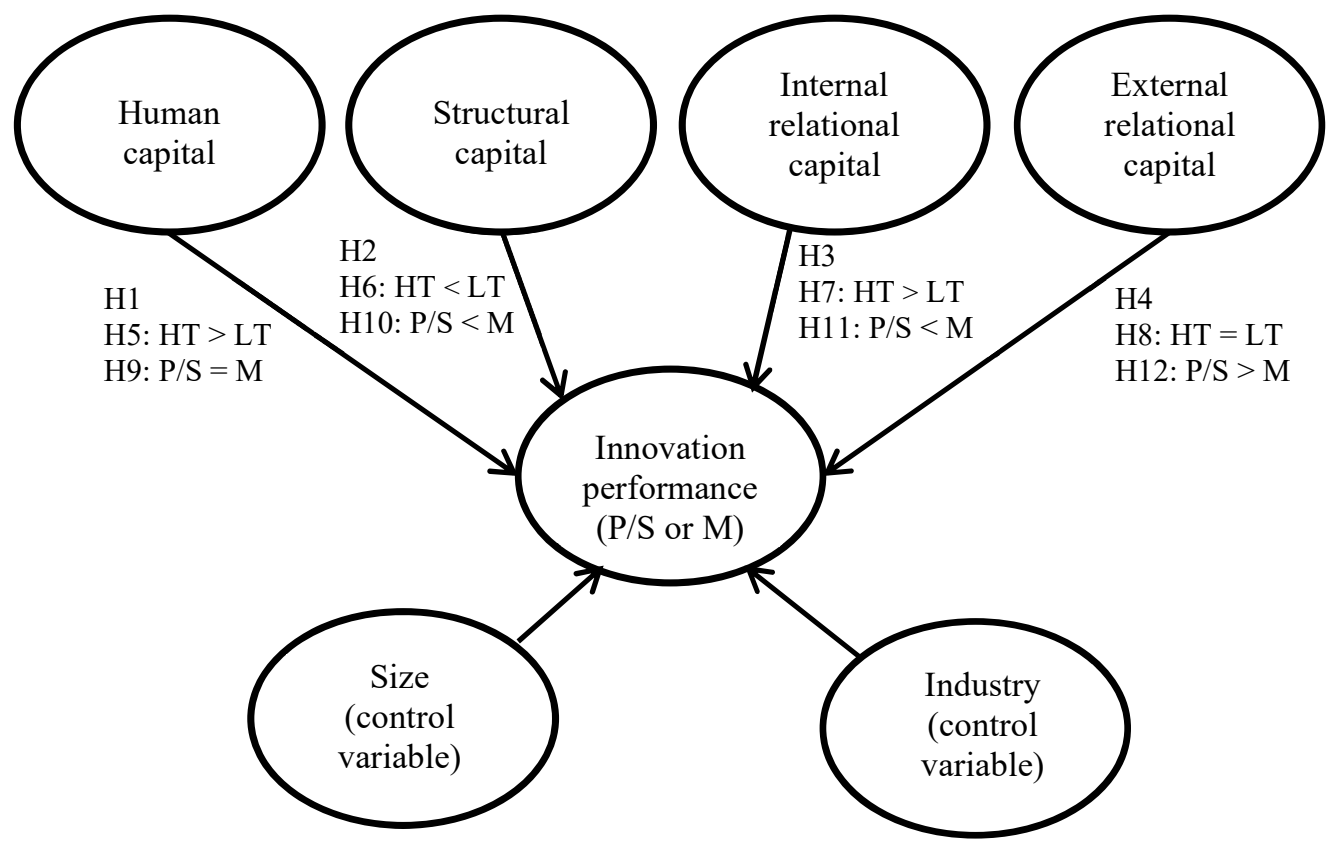

Figure 2. Post hoc analyses: Potential indirect effects on MIP in HT firms

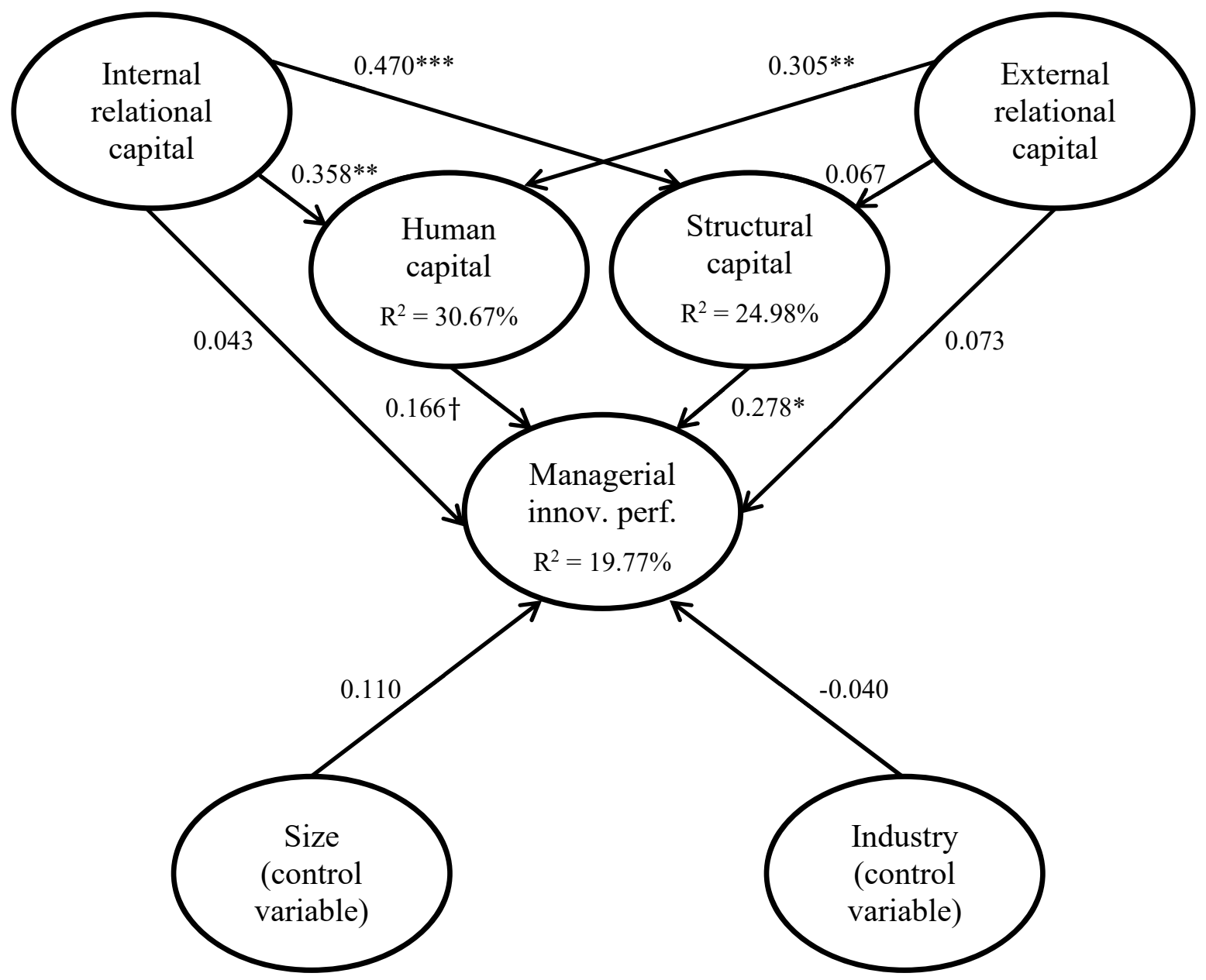

Notes: $* * * \mathrm{p}<0.001, * * \mathrm{p}<0.01,{ }^{*} \mathrm{p}<0.05,+\mathrm{p}<0.1$ (based on $\mathrm{t}_{499}$, one-tailed test). 
Figure 3. Post hoc analyses: Potential indirect effects on MIP in LT firms

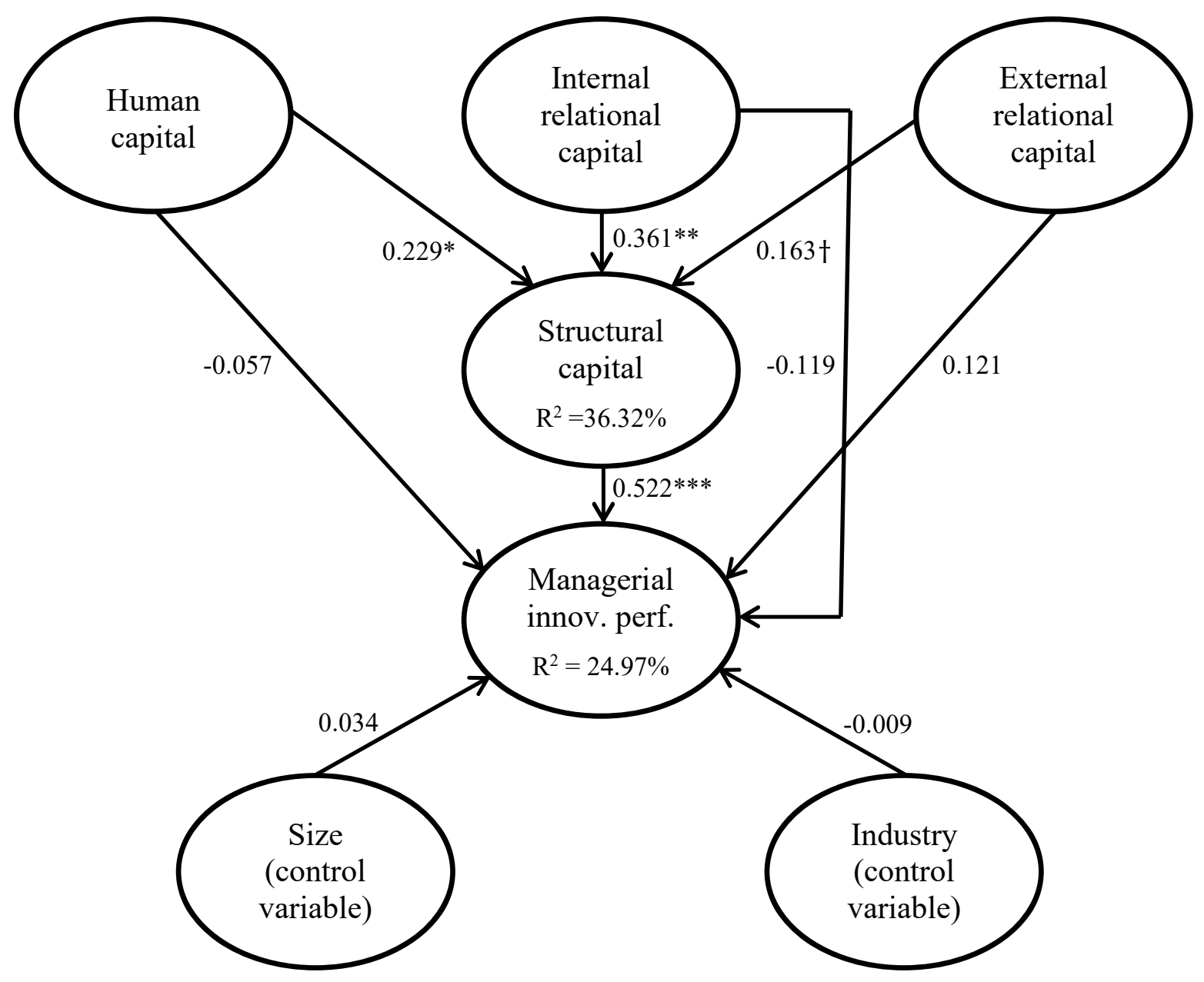

Notes: $\quad * * * \mathrm{p}<0.001, * * \mathrm{p}<0.01,{ }^{*} \mathrm{p}<0.05,+\mathrm{p}<0.1$ (based on $\mathrm{t}_{499}$, one-tailed test). 